\title{
СТОМАТОЛОГІЯ
}

\section{АНАЛІЗ ЕФЕКТИВНОСТІ ВИКОРИСТАННЯ РІЗНИХ КЛІТИННИХ ТЕХНОЛОГІЙ У ПРАКТИЧНІЙ СТОМАТОЛОГї}

\begin{abstract}
Резюме. Розвиток сучасної імплантологічної галузі, що дозволяє провести ефективну реабілітацію стоматологічних пацієнтів у випадках часткової та повної адентії, передбачає скорочення кількості відносних протипоказань до встановлення титанових інтраосальних конструкцій, особливо у випадках дефріциту кісткової тканини чи недостатніх геометричних параметрах резидуального гребеня.

Мета дослідження - проаналізувати результати застосування принципів клітинної інженерії у стоматологічній практиці за даними проведених клінічних, лабораторних та експериментальних досліджень, опублікованих у періодичних наукових виданнях та обґрунтувати потребу систематизації різних підходів до підвищення есрективності реконструктивних маніпуляцій у щелепно-лицевій ділянці.

Матеріали і методи. В ході ретроспективного аналізу літературних джерел було проаналізовано 98 наукових публікацій, 3 яких дані 32 були детально репрезентовані як такі, що значно відрізняються або ж представляють різні якісні підходи реконструктивних маніпуляцій у стоматологічній практиці. Пошук первинних даних проводили з використанням пошукової системи Google Scholar за ключовими словами, з формулюванням пошукового запиту у вигляді окремих слів або ж словосполучень. Вибірку відповідних публікацій здійснювали з використанням методу контент-аналізу, принципи використання якого дозволили систематизувати результати цільових наукових досліджень у програмному забезпеченні Microsoft Excel 2013 (Microsoft Office, 2013).

Результати досліджень та їх обговорення. Проведено аналіз застосування принципів клітинної інженерії у стоматологічній практиці за даними клінічних, лабораторних та експериментальних досліджень, дозволяє зробити висновок про складність систематизації отриманих результатів, у зв'язку із різним методологічним підходом до проведення досліджень, використанням різних параметрів оцінки вихідних та кінцевих результатів, та відмінністю цільового призначення того чи іншого методу регенераторної терапії - від фрактичного відновлення певного об'єму кісткової тканини до підтвердження думки про існуючий регенераторний потенціал.

Висновки. Подальша розробка та модифрікація існуючих підходів регенеративної терапії матеріалами 3 покоління за Еgusa (2012) забезпечує підвищення есективності проведення різних типів реконструктивних втручань у щелепно-лицевій ділянці, а відсутність відповідних алгоритмів менеджменту стовбурових клітин, їх адекватного збору та трансферу з подальшою підсадкою залишається актуальними питаннями регенераторної терапії в стоматології.
\end{abstract}

Ключові слова: клітинна інженерія; реконструктивні маніпуляції; стоматологічна практика.

ВСтУп Розвиток сучасної імплантологічної галузі, що дозволяє провести ефективну реабілітацію стоматологічних пацієнтів у випадках часткової та повної адентії, передбачає скорочення кількості відносних протипоказань до встановлення титанових інтраосальних конструкцій, особливо у випадках дефріциту кісткової тканини чи недостатніх геометричних параметрах резидуального гребня [1, 2]. Така тенденція аргументована паралельним прогресивним розширенням можливостей направленої кісткової реконструкції з використанням різних типів трансплантатних та допоміжних матеріалів, що забезпечують прогнозовану регенерацію кістки з відновленням параметрів не тільки її висоти і ширини, а й відповідних якісних характеристик [3-6]. Найбільш перспективним вектором розвитку регенераторної терапії залишається застосування різних біологічних середників, котрі сприяють досягненню більш ефективних і прогнозованих результатів аугментації. За даними H. Egusa (2012), прогрес при застосуванні принципів регенераторної терапії у стоматології умовно можна розділити на 5 поколінь та два принципи: на основі модифрікації різних матеріалів та на основі використання стовбурових клітин $[7,8]$. Перші два покоління систематизації Egusa представлено мембранами для направленої тканинної регенерації, матеріалами на основі кальцію фоссрату, гідроксилапатиту, бетатрикальційфосфату, плазми, збагаченої тромбоцитами, середниками з вмістом кісткових морфогенетичних білків та інших фракторів росту. Дані матеріали відрізняються тим, що, на думку автора, систематизації не проявляють остеоіндуктивних властивостей. До 3 покоління біоматеріалів було віднесено стовбурові клітини кісткового мозку, періостальні клітини-попередники, клітини-попередники 3 ділянки пульпи та ін. 4 покоління являє собою тривимірні конструкції із складовими клітинами, які забезпечують чітко визначену диференціацію з відновленням відповідної гістологічної структури, разом з тим, як 5 передбачає використання уже біоінженерно модифрікованих клітин для повної аналогічної заміни органів або ж їх частин. Логічно, що остеоіндуктивний потенціал біологічних матеріалів 3-5 поколінь прогресивно зростає. Проте перспектива подальшого вдосконалення методів та підходів до регенерації тканин зубощелепного апарату базується на забезпеченні деталізованого аналізу всіх можливостей саме 3 покоління матеріалів, як первинного в арсеналі остеоіндуктивної терапії та відносно доступного у клінічній практиці, в той час, як матеріали 4-5 поколінь залишаються вихідними для проведення лабораторних та експериментальних досліджень. Виходячи із вищенаведеного, можна резюмувати, що аналіз можливостей та результатів застосування біоматеріалів 3 покоління за Egusa у розрізі комплексної оцінки ефективності застосування регенераторної терапії у стоматологічній практиці є достатньо актуальним теоретичним питанням, а десріцит відповідних вітчизняних публікацій 
підтверджує доцільність систематизації даних, отриманих в ході попередніх клінічних та лабораторних досліджень.

Метою дослідження було проаналізувати результати застосування принципів клітинної інженерії у стоматологічній практиці за даними проведених клінічних, лабораторних та експериментальних досліджень, опублікованих у періодичних наукових виданнях та обґрунтувати потребу систематизації різних підходів до підвищення есрективності реконструктивних маніпуляцій в щелепнолицевій ділянці.

МАТЕРІАЛИ І МЕТОДИ У ході ретроспективного аналізу літературних джерел було проаналізовано 98 наукових публікацій, з яких дані 32 були детально репрезентовані як такі, що значимо відрізняються або ж представляють різні якісні підходи реконструктивних маніпуляцій у стоматологічній практиці. Пошук первинних даних проводили з використанням пошукової системи Google Scholar за ключовими словами, з формулюванням пошукового запиту у вигляді окремих слів або ж словосполучень "клітинна інженерія", "клітинні технології", "стоматологія", "аугментація кісткової тканини", "регенераторний потенціал". Для оптимізації процесу пошуку необхідної інсрормації використовували фрорми складних запитів, за допомогою яких вдається розширити пошукові можливості інфрормаційної мережі. Для більш швидкого й успішного пошуку разом із ключовими словами використовували логічні оператори та синтаксичні вирази, завдяки яким вдається знайти не тільки повні відповідності слів у контексті об'єму інорормації, а й суміжні дані, що в окремих випадках мають опосередкований зв'язок із тематикою запиту. Вибірка відповідних публікацій здійснювали з використанням методу контент-аналізу, принципи використання якого дозволили систематизувати результати цільових наукових досліджень у програмному забезпеченHi Microsoft Excel, 2013 (Microsoft Office, 2013), 3 подальшим їх аналітичним групуванням за різновидом дослідження, величиною чисельних результатів, вихідними параметрами оцінки, метою та використовуваними методами реєстрації. Статті, відібрані для деталізованого аналізу, були опубліковані в період з 2000 до 2013 року. Інтерпретацію результатів проводили відповідно до основної мети дослідження.

РЕЗУЛЬТАТИ ДОСЛІДЖЕНЬ ТА ЇХ ОБГОВОРЕННЯ Аспект ідентифрікації плюрипотентних клітин у відповідній кількості чи концентрації в конкретних тканинах організму досі залишається актуальним питання сучасної клітинної інженерії, проте наявність таких реєструють за непрямими ознаками, за типом експресії відповідних середників, верифрікації особливостей клітинного циклу чи клоногенністю. G. Bluteau та H. Luder із Університету Цюріху в 2008 р. провели категоризацію застосування стовбурових клітин у стоматологічній практиці, виходячи із особливостей їх походження та перспектив застосування: мезенхімальні стовбурові клітини (можуть диференціювати у мезодермальну лінію клітин 3 нарощуванням потенціалу до формування хрящової, кісткової, жирової тканин, скелетної мускулатури та строми сполучної тканини), стовбурові клітини з ділянки молочних зубів (можуть диференціювати в нейрони, адипоцити, остеобласти та одонтобласти та стимулювати утворення дентину чи кістки, проте без можливості індукції розвитку дентиннопульпульного комплексу), стовбурові клітини ділянки пульпи у дорослих (з можливістю відновлення дентинного матриксу у відповідь на конкретні біологічні сигнали, при цьому перицити пульпи можуть дисеренціювати навіть в остеобласти), стовбурові клітини з апікальної частини сосочка (доведено, що мають вищий регенераторний потенціал, ніж стовбурові клітини періодонтальної зв'язки відносно відновлення окремих тканин зуба), стовбурові клітини 3 дентальних фролікул (доказово можуть диференціювати в цементобласти та здатні відновлювати періодонтальну зв'язку), стовбурові клітини періодонтальної зв'язки (перспективні для стимулювання процесу регенерації кісткової тканини та цементу кореня), стовбурові клітини з ділянки кісткового мозку (демонструють вищий регенераторний потенціал щодо кісткової тканини та нижчий відносно зубних структур, що обґрунтовано мезодермальним походженням), епітеліальні клітини $з$ молярів, що розвиваються (проблематичний аспект використання у зв'язку з необхідністю забору біологічного матеріалу від дітей) [9]. Перспективні дослідження продовжують проводити 3 метою верифрікації потенціалу стовбурових клітин із зубів гризунів, оскільки особливість останніх полягає у тому, що вони продовжують рости упродовж усього життя. Автори також запропонували специфрічну блок-схему можливості відтворення зубної структури в лабораторних умовах, яка передбачала обов'язкове залучення стовбурових клітин із вихідної тканини, вплив фракторів росту, наявність біологічного каркасу та специфічних субопопуляцій клітин, які в подальшому дозволять сорормувати відповідний біологічний алгоритм дисреренціації гістологічних структур [9]. Аналогічний підхід є дієвим і для відновлення кісткової тканини та оптимізований уже наявною кількістю доказових даних щодо можливостей регенерації кістки 3 використанням різного роду остеотрансплантатів.

M. V. Risburd та I. M. Shapiro (2005) наголосили на тому, що використання мезенхімальних клітин як популяції плюрипотентних попередників обґрунтоване перспективою їх диференціації у специфічні клітини з подальшим гістологічним розвитком оточуючої структури [10]. Таким чином, напрямок та тенденція даного процесу залежать від умов забору та зберігання відповідних біологічних одиниць та впливу навколишнього середовища через низку відповідних сигналів, що потенціюють диференційований характер розвитку стовбурових попередників. Більш глибоке розуміння механізмів специфрікації клітин та їх морфогенезу забезпечить розробку оптимальних та раціональних підходів до використання можливостей клітинної інженерії у практиці щелепнолицевої хірургії та клінічної стоматології. Первинним етапом дослідження повинна бути саме систематизаціяіснуючих на сьогодні результатів попередніх клінічних та лабораторних досліджень, котрі дозволять сформулювати певні висновки щодо невирішених проблем даної галузі та тенденцій її розвитку і вдосконалення як проміжного етапу перед виконанням авторських експериментальних досліджень у даній галузі.

T.-J. Huang та колеги (2010) змогли досягнути регенерації пульпоподібної тканини у зубі, пересадженого миші, за допомогою стовбурових клітин пульпи та прогеніторних клітин, зібраних із ділянки сосочка. Крім того, вченим також вдалось довести фракт фрормування дентиноподібної структури навколо неоваскуляризованої тканини, клітини котрої вели себе дуже схоже до одонтобластів, забезпечуючи експресію дентинного сіалопротеїну, кісткового сіалопротеїну, лужної фоосфатази та CD105. Необхідно також відмітити, що клітини пульпопо- 
дібної тканини позитивно реагували на мітохондріальні антитіла людини, що свідчить про їх походження із тканин організму [11]. W. Sonoyama, T.-J. Huang та співавт. (2006) також активно працювали над розробкою відповідних живильних середовищ для вирощування клітин-попередників у найоптимальніші строки, таким чином, закладаючи перші основи до протоколів провадження клітинної інженерії у практичній стоматологічній діяльності особливу увагу при цьому звертали на перспективу відновлення кісткових десектів, що найчастіше зустрічаються у стоматології [12]. Цікаві результати отримали S. Gronthos та колеги (2000): дослідники виділили постнатальні стовбурові клітини дентальної пульпи і довели, що дані клітини в експериментальних умовах демонструють у декілька разів більший потенціал фрормування дентиноподібної (кісткоподібної) субстанції, а ніж в природних умовах організму [13]. Таким чином, на думку дослідників, дилема полягає лише у розробці відповідних алгоритмів менеджменту стовбурових клітин, їх адекватного збору та трансферу з подальшою підсадкою, що забезпечить новий прогресивний розвиток у практиці кісткових аугментацій зубощелепного апарату.

Порівняльний аналіз стромальних клітин пульпи зуба та кісткового мозку провів S. Shi (2001) за допомогою кДНК мікроматричного методу [14]. Вченому вдалось встановити, що стромальні стовбурові клітини пульпи більш прогресивно забезпечують експресію генів, що контролюють експресію колагену типу 8-альфра-1, інсуліноподібного фрактора росту-2, дискординового домену тирозин-кінази-2, циклінзалежної кінази-6, разом з тим, як стромальні клітини кісткового мозку провокували експресію інсуліноподібного фрактора зв'язку з протеїном-7 і колагену типу 1-альсра-2. Перспектива подальшого аналізу аналогічних досліджень полягає у формуванні відповідної вибірки необхідних біологічних маркерів, які б дозволили чітко диореренціювати різницю впливу відповідних генів на формування кістки та дентиноподібних структур залежно від показників інтенсивності регуляторних та регенеративних процесів, ролі суміжних імунологічних реакцій та характеру прогнозованості специфічних протоколів клітинної інженерії. C. Morsczeck та колеги (2004) довели існування клітин-попередників у складі зубного фролікула зуба мудрості, попередньо обґрунтувавши своє припущення тим, що фолікул по своїй суті являє не що інше як ектомензенхімальну тканину, котра оточує зачаток зуба [15]. В експерименті з підсадкою вилучених клітин-попередників мишам 3 провокованою імунною супресією вдалось довести, що дані клітини по-різному проявляють експресію остеокальцину і кісткового сіалопротеїну, однак так і не було отримано фрактів щодо участі їх у фрормуванні нових цементних чи кісткових структур. Отримані результати лише підтверджують первинну гіпотезу щодо того, що перед прорізуванням зуба в структурі його періодонта містяться представники лінійки клітин-попередників, що можуть проходити через наступний процес дифреренціації залежно від впливу різних біологічних фракторів.

У дослідженні, проведеному М. А. Costa та співавт. (2008), було встановлено, що насправді стовбурові клітини людської пульпи являються активними відносно реакції на маркери остеогенної, адипогенної та міогенної диференціацій, специфрікація ж процесів залежить більшою мірою від вихідних умов ділянки трансплантації [16]. Даному колективу дослідників вдалось відновити значний краніальний дефект із застосуванням стовбурових клітин пульпи, та при цьому розробити відповідний прогностичний модуль подібних реконструкцій з можливим перспективними використанням потенціалу недиференційованих клітин-попередників. В умовах лабораторної індукції Xi Wei (2008) встановив, що реєстрація таких маркерів, як позаклітинних матричних фросфроглікопротеїнів разом 3 дентинним сіалопротеїном може слугувати ознакою одонтогенного потенціалу досліджуваних клітин, разом з тим, як верифрікації одночасно дентинного сіалопротеїну та остеокальцину може свідчити про переважаючий остеогенний потенціал експериментальної культури [17].

У ранніх дослідженнях Y. Yamada та колеги (2008) довели ефрективність використання аутогенних стромальних клітин кісткового мозку при проведенні операцій синус-ліфрту. В якості біологічного каркасу при виконанні операційних втручань використовували PRP-згустки [4]. Середній вертикальний приріст кістки через 2 роки після аугментації складав близько $(8,8 \pm 1,6) \mathrm{mm}$ порівняно з вихідними значеннями. Жодних прогресивних резорбтивних змін резидуального гребня в ділянці установлених після агументації імплантатів у період моніторингу через 2-6 років у ділянці жодної із 46 інсрраконструкцій не спостерігалось. Даний ін'єкційний метод, на думку авторів, забезпечує прогнозовані результати аугментації та зводить об'єм хірургічного вручання до обґрунтованого мінімуму. Пізніше в ході лабораторних досліджень Ү. Yamada та колеги (2010) довели, що використання стовбурових клітин пульпи зуба, стовбурових клітин молочних зубів та мезенхімальних клітин кісткового мозку стимулює експресію таких остеогенетичних маркерів, як STRO-1, CD13, CD29, CD44, CD73, а також лужної фроссратази та остеокальцину $[3,5]$. При клінічному використанні даних культур клітин разом із плазмою, збагаченою тромбоцитами, вдалось довести можливість формування зрілої кісткової тканини та відповідної неоваскуляризаціїі в області аугментованих ділянках навколо імплантатів із гідроксиапатитним покриттям. Перевага стовбурових клітин молочних клітин чи пульпи зуба, на думку авторів, полягає у менш інвазивних процедурах забору та можливості їх культивування в лабораторних умовах. При цьому важливою знахідкою було доведення того, що стовбурові клітини молочних зубів не провокують відторгнення алогенного трансплантата. Додатково було встановлено, що ізольоване використання плазми, збагаченої тромбоцитами, не сприяє підвищенню показника \% контакту кісткової тканини $з$ імплантатом, разом з тим, дослідження даного показника в динаміці з різними видами клітин, які використовують, залишається актуальним питання як клінічної імплантології, так і прикладної клітинної інженерії.

S.-H. Kim та колеги (2009) після використання стовбурових клітин кісткового мозку та періодонтальної зв'язки в умовах експериментально іммітованої біологічної моделі периімплантиту встановили, що показники фрормування нової кісткової тканини були найвищими при використанні саме кістково-клітинного деривату (34,99 та 40,17\% через 8 і 16 місяців після аугментації відповідно) [18]. Аналогічні показники при використанні культури клітин із ділянки періодонтальної зв'язки були майже у 1,5 раза нижчими. При цьому статистично достовірні показники ефективності відновлення кісткової тканини, порівняно з контрольною групою, через 16 тижнів були доведені лиш у випадках використання клітин-попередників кісткового мозку, що може свідчити про їх більш виражений потенціал для заміщення периімплантатних десектів. 
Нові дослідження K. Ito та колег (2011) виявили, що використання стовбурових клітин пульпи зуба разом із плазмою, збагаченою тромбоцитами, сприяє фрормуванню контакту між кісткою та імплантатом на рівні $(66,7 \pm 3,6)$ $\%,(62,5 \pm 3,1) \%$ при використанні PRP зі стовбуровими клітинами кісткового мозку та $(39,4 \pm 2,4) \%$ при використанні періостальних клітин з PRP через 8 тижнів після установки імплантатів [5]. Для порівняння величина даного показника у контрольній групі в аналогічні терміни моніторингу не перевищувала $(30,3 \pm 2,6) \%$. Аналогічні дані було отримано C. Estrela (2011), який з колегами проаналізували можливості застосування різних типів стовбурових клітин, котрі перспективно можна використати для відновлення дефектів альвеолярного/резидуального гребеня, заміщення периімплантаційних та пародонтальних дефектів та окремих зубних структур [19].

R. Schimming та Schmelzeisen (2004) також звернули увагу на те, що ефективність аугментаційних процедур залежить від таких факторів, як спосіб доставки остеобластів у ділянку десректу, природи біологічного каркасу, в якості котрого використовували дослідження Ethisorb (Ethicon, Norderstedt, Germany) та розміру дефекту [20]. У 8 з 27 випадків успішного результату досягнути не вдалось через достатньо великі розміри кісткового десректу, проте у 18 пацієнтів довелось досягти вдалого фрормування пластинчастої кістки на достатньому біологічному матриксі уже через 3 місяці після аугментації, що підтверджує первинну думку авторів про те, що використання періостальних остеобластів на відповідному біологічному каркасі забезпечує реставрацію проблемної кісткової ділянки в оптимально прийнятні строки. M. Riccio (2011) також підтвердив значимість біологічного скефолду на параметри відновлення десректів кісткової тканини в експерименті на щурах [21]. Дослідник встановив, що фріброїновий каркас забезпечує формування зрілої кісткової тканини як при застосуванні стовбурових клітин із пульпи зуба, так і при використанні стовбурових клітин з амніотичної рідини. Проте останній підхід забезпечував все ж більший приріст кісткової тканини в ділянці дефекту, що однак не демонстрував значимої статистичної різниці. S. Y. Shayeste та колеги (2008), досліджуючи перспективу застосування мезенхімальних стовбурових клітин під час процедури синус-лісту, встановили, що комбіноване використання біологічних середників разом із біфразним гідроксилапатитом/бетакальційсроссратом дозволяє досягти успішних сумісних результатів реконструктивного втручання та подальшої імплантації у 93 \% випадків [22]. Середній рівень регенерації кісткової тканини становив 41,34 \% відносно вихідного, а середній абсолютний приріст кістки - 12,08 мм та 10,08 мм через 3 та 12 місяців відповідно. Очевидно, використання мезенхімальних клітин разом із кістковим дериватом у ході виконання операції синус-лісту стимулює фрормування кістки, проте для фрормулювання однозначних висновків необхідне проведення більш деталізованих та розширених клінічних досліджень. Т. Matsubara та колеги (2004) також звернули увагу на те, що навіть при використанні стовбурових клітин кісткового мозку велике значення відіграє топографрія забору біоматеріалу [23]. На прикладі порівняння аспіратів із кісткового мозку альвеолярної кістки та клубової кістки, дослідники довели, що перший субстрат демонструє нижчі хондрогенні та адипогенні потенціали, що у випадках його використання в стоматології можна розцінювати як важливу структурну-регенеративну перевагу, особливо у випадках лікування окремих захворювань чи травм кісток зубощелеп- ного апарату. 3 іншого боку, C. Zizelman та колеги (2006) довели, що використання аутолоічного трансплантата для синус-ліфту є більш прогнозованим, ніж використання поліглікоїдного-полілактидного біологічного каркасу з інфрільтрованими остеобластами [6]. В ході експерименту дослідники відмітили, що рівень резорбції кістки у другому випадку сягав майже 90 \%, а ступінь її щільності не перевищував 152 одиниць Хаунсвільда (на противагу 266-551 одиницям Хаунсвільда при виконанні аугментації аутологічним кістковим блоком).

H. F. Cerruti та колеги (2007) на основі проаналізованих клінічних випадків дійшли висновку, що використання плазми, збагаченої тромбоцитами, та мононуклеарних клітин, зібраних із аспіратів кісткового мозку, разом із біологічним алогенним каркасом сприяє інтеграції трансплантата та його адаптації до кортикальної кістки щелепи [24]. Аналогічні результати отримав A. Gonshor (2011), довівши більш ефективний результат аугментації з використанням алографту, що містив стовбурові клітини в матриці трансплантата, порівняно зі звичайним алотрансплантатом [13]. При цьому в ході ремоделювання кісткової тканини в ділянці дефекту модифрікованим алографтом рівень його резидуального залишку складав в середньому $(4,9 \pm 2,4) \%$, разом 3 тим, як при використання звичайного алотрансплантата - $(25,8 \pm 13,4) \%$. Srouji S. та колеги (2011), досліджуючи френомен утворення кісткової тканини при елевації шнайдерової мембрани та без використання додаткових трансплантатних матеріалів, виявили значний регенераторний потенціал мембрани через ряд маркерів мезенхімальних клітинпопередників (CD 105, CD 146, CD 71, CD 73, CD 166) [26]. В експерименті при контакті клітин мембрани з остеокондуктивним каркасом вдалось зареєструвати остеогенетичний потенціал такої, що в подальшому можна використовувати для модисрікацій методик проведення синус-ліфту та забезпечення прогнозованих результатів лікування з мінімальним використанням кістковозамінних матеріалів.

Ј. Ј. Мао (2012) звернув увагу, що розвиток клітинної інженерії у галузі реконструктивної стоматології багато в чому залежить від механізму контролю та регуляції подібних лікувальних підходів з боку різних установчих структур шляхом розробки алгоритмів збору, вирощування та діагностики відповідних фоорм біологічних матеріалів [26].

ВИСНОВКИ Проведений аналіз застосування принципів клітинної інженерії у стоматологічній практиці за даними клінічних, лабораторних та експериментальних досліджень дозволяє зробити висновок про складність систематизації отриманих результатів, у зв'язку із різним методологічним підходом до проведення досліджень, використанням різних параметрів оцінки вихідних та кінцевих результатів, та відмінністю цільового призначення того чи іншого методу регенераторної терапії - від фрактичного відновлення певного об'єму кісткової тканини до підтвердження думки про існуючий регенераторний потенціал.

Перспективи подальших досліджень У всіх проаналізованих дослідженнях було підтверджено думку про перспективу застосування даної технології у клінічній стоматологічній практиці, оскільки результати імплементації принципів клітинної інженерії у жодному із проаналізованих випадків не компрометували кінцевого результату стоматологічної реабілітації, а навпаки, сприяли досягненню більш якісного результату через покращення кількісних параметрів кісткової тканини, збільшенню її 
геометричних розмірів, порівняно з вихідною ситуацією, скороченню терміну лікування, позитивну динаміку змін морфометричних та гістологічних показників. Таким чином, подальша розробка та модифрікація підходів регене- ративної терапії матеріалами 3 покоління за Egusa (2012), що існують, забезпечує підвищення ефрективності проведення різних типів реконструктивних втручань у щелепно-лицевій ділянці.

\section{СПИСОК ЛІТЕРАТУРИ}

1. Hwang D. Medical contraindications to implant therapy: Part II: Relative contraindications / D. Hwang, H. L. Wang // Implant Dentistry. - 2007. - Vol. 16, No. 1. - P. 13-23.

2. Misch C. E. Endosteal implants for posterior single tooth replacement: alternatives, indications, contraindications, and limitations / C. E. Misch // Journal of Oral Implantology. - 1999. Vol. 25, No. 2. - P. 80-94.

3. A feasibility of useful cell-based therapy by bone regeneration with deciduous tooth stem cells, dental pulp stem cells, or bonemarrow-derived mesenchymal stem cells for clinical study using tissue engineering technology / Y. Yamada, S. Nakamura, K. Ito [et al.] //Tissue Engineering Part A. - 2010. - Vol. 16, No. 6. P. $1891-1900$

4. Injectable tissue-engineered bone using autogenous bone marrow-derived stromal cells for maxillary sinus augmentation: clinical application report from a 2-6-year follow-up / Y. Yamada, S. Nakamura, K. Ito [et al.] // Tissue Engineering Part A. - 2008. Vol. 14, No. 10. - P. 1699-1707.

5. Promising cell-based therapy for bone regeneration using stem cells from deciduous teeth, dental pulp, and bone marrow $/$ Y. Yamada, K. Ito, S. Nakamura [et al.] //Cell transplantation. -2011. - Vol. 20, No. 7. - P. 1003-1013.

6. Bone formation after sinus augmentation with engineered bone / C. Zizelmann, R. Schoen, M. C. Metzger [et al.] // Clinical Oral Implants Research. - 2007. - Vol. 18, No. 1. - P. 69-73.

7. Stem cells in dentistry-part I: stem cell sources / H. Egusa, W. Sonoyama, M. Nishimura [et al.] // Journal of Prosthodontic Research. - 2012. - Vol. 56, No. 3. - P. 151-165.

8. Stem cells in dentistry-Part II: Clinical applications / H. Egusa, W. Sonoyama, M. Nishimura [et al.] // Journal of Prosthodontic Research. - 2012. - Vol. 56, No. 4. - P. 229-248.

9. Stem cells for tooth engineering / G. Bluteau, H. U. Luder, C. De Bari, T. A. Mitsiadis // Eur. Cell Mater. - 2008. - Vol. 16. P. 1-9.

10. Risbud M. V. Stem cells in craniofacial and dental tissue engineering / M. Risbund, I. M. Shapiro // Orthodontics \& Craniofacial Research. - 2005. - Vol. 8, No. 2. - P. 54-59.

11. Huang G. T. J. Pulp and dentin tissue engineering and regeneration: current progress / G. T. J. Huang // Regenerative Medicine. - 2009. - Vol. 4, No. 5. - P. 697-707.

12. In vitro characterization of human dental pulp cells: various isolation methods and culturing environments / G. T. J. Huang, W. Sonoyama, J. Chen, S. H. Park // Cell and Tissue Research. 2006. - Vol. 324, No. 2. - P. 225-236.

13. Histologic and histomorphometric evaluation of an allograft stem cell-based matrix sinus augmentation procedure / A. Gonshor, B. McAllister, S. S. Wallace, H. Prasad // International Journal of Oral \& Maxillofacial Implants. - 2011. - Vol. 26, No. 1.
14. Shi S. Comparison of human dental pulp and bone marrow stromal stem cells by cDNA microarray analysis / S. Shi, P. G. Robey, S. Gronthos // Bone. - 2001. - Vol. 29, No. 6. - P. 532-539.

15. Somatic stem cells for regenerative dentistry / C. Morsczeck, G. Schmalz, T. E. Reichert [et al.] // Clinical Oral Investigations. 2008. - Vol. 12, No. 2. - P. 113-118.

16. Reconstruction of large cranial defects in non-immunosuppressed experimental design with human dental pulp stem cells / A. de Mendonça Costa, D. F. Bueno, M. T. Martins [et al.] // Journal of Craniofacial Surgery. - 2008. - Vol. 19, No. 1. - P. 204-210.

17. Differentially expressed protein profile of human dental pulp cells in the early process of odontoblast-like differentiation in vitro / X. Wei, L. Wu, J. Ling [et al.] // Journal of Endodontics. - 2008. Vol. 34, No. 9. - P. 1077-1084.

18. Alveolar bone regeneration by transplantation of periodontal ligament stem cells and bone marrow stem cells in a canine peri-implant defect model: a pilot study / S. H. Kim, K. H. Kim, B. M. Seo [et al.] // Journal of Periodontology. - 2009. - Vol. 80, No. 11. - P. 1815-1823.

19. Mesenchymal stem cells in the dental tissues: perspectives for tissue regeneration / C. Estrela, A. H. G. D. Alencar, G. T. Kitten [et al.] // Brazilian Dental Journal. - 2011. - Vol. 22, No. 2. - P. 91-98.

20. Schimming R. Tissue-engineered bone for maxillary sinus augmentation / R. Schimming, R. Schmelzeisen // Journal of Oral and Maxillofacial Surgery. - 2004. - Vol. 62, No. 6. - P. 724-729.

21. Fibroin scaffold repairs critical-size bone defects in vivo supported by human amniotic fluid and dental pulp stem cells / M. Riccio, T. Maraldi, A. Pisciotta [et al.] // Tissue Engineering Part A. - 2012. - Vol. 18, No. 9-10. - P. 1006-1013.

22. Sinus augmentation using human mesenchymal stem cells loaded into a $\beta$-tricalcium phosphate/hydroxyapatite scaffold / Y. S. Shayesteh, A. Khojasteh, M. Soleimani [et al.] // Oral Surgery, Oral Medicine, Oral Pathology, Oral Radiology, and Endodontology. - 2008. - Vol. 106, No. 2. - P. 203-209.

23. Matsubara T. Alveolar bone marrow as a cell source for regenerative medicine: differences between alveolar and iliac bone marrow stromal cells / T. Matsubara, K. Suardita, M. Ishii [et al.] // Journal of Bone and Mineral Research. - 2005. - Vol. 20, No. 3. P. 399-409.

24. Allogenous bone grafts improved by bone marrow stem cells and platelet growth factors: clinical case reports / H. Cerruti Filho, I. Kerkis, A. Kerkis [et al.] // Artificial Organs. - 2007. - Vol. 31, No. 4. - P. 268-273.

25. The Schneiderian membrane contains osteoprogenitor cells: in vivo and in vitro study / S. Srouji, T. Kizhner, D. B. David [et al.] // Calcified Tissue International. - 2009. - Vol. 84, No. 2. - P. 138-145.

26. Mao J. J. Stem cells in the face: tooth regeneration and beyond I J. J. Mao, D. J. Prockop // Cell Stem Cell. - 2012. - Vol. 11, No. 3. - P. 291-301. 


\section{ANALYSIS OF DIFFERENT CELL TECHNOLOGIES USE IN PRACTICAL DENTISTRY}

Summary. The development of the modern implantology industry, which allows for the effective rehabilitation of dental patients in cases of partial and complete adentia, involves reducing the number of relative contraindications to the establishment of titanium intralesional structures, especially in cases of bone defect or insufficient geometric parameters of the residual crest.

The aim of the study - to analyze the results of cell engineering principles use in dental practice based on data from clinical, laboratory and experimental studies published in scientific periodical journals, and justify the need for systematization of different approaches to improve the efficiency of such manipulations during the reconstruction activities in maxillofacial area.

Materials and Methods. During the retrospective analysis of the literature 98 scientific publications were evaluated, of which 32 were represented in detailed manner as such that significantly differ or represent different qualitative approaches for reconstructive manipulation in dental practice. Primary data search was conducted using Google Scholar engine by keywords and formulation of search task based on individual words or phrases. The sample of relevant publications was formed using the method of content analysis, principles of which allowed us to systematize the results of research in the software Microsoft Excel 2013 (Microsoft Office, 2013).

Results and Discussion. The analysis of the principles of cell engineering in dental practice according to the clinical, laboratory and experimental research data suggests the complexity of the systematization for such type of results due to the different methodological approaches, different valuation parameters for initial and final results, and different purposes of a regeneratory therapy, that were used in previous studies. Some studies evaluated the actual recovery of a certain bone volume, but others just confirm the presence of existing regenerative potential.

Conclusions. Further development and modification of existing approaches for regenerative therapies with the use of third generation materials by Egusa (2012), enhances the effectiveness of various types of reconstructive surgery in maxillofacial area, and the lack of appropriate algorithms for stem cells management, their adequate collection and transfer remains questionable within regeneratory therapy in dental practice

Key words: cell engineering; reconstructive manipulation; dental practice.

๔ОО. Л. Белей, М. Ю. Гончарук-Хомин

Ужгородский национальный университет

\section{АНАЛИЗ ЭФФЕКТИВНОСТИ ИСПОЛЬЗОВАНИЯ РАЗНЫХ КЛЕТОЧНЫХ ТЕХНОЛОГИЙ В ПРАКТИЧЕСКОЙ СТОМАТОЛОГИИ}

Резюме. Развитие современной имплантологической отрасли, что позволяет провести эфрфективную реабилитацию стоматологических пациентов в случаях частичной и полной адентии, предусматривает сокращение количества относительных противопоказаний к установлению титановых интраосальных конструкций, особенно в случаях десицита костной ткани или недостаточных геометрических параметрах резидуального гребня.

Цель исследования - проанализировать результаты применения принципов клеточной инженерии в стоматологической практике по данным проведенных клинических, лабораторных и экспериментальных исследований, опубликованных в периодических научных изданиях, и обосновать необходимость систематизации различных подходов к повышению эсфрективности реконструктивных манипуляций в челюстно-лицевой области.

Материалы и методы. В ходе ретроспективного анализа литературных источников были проанализированы 98 научных публикаций, из которых данные 32 были подробно представлены как такие, что значимо отличаются или представляют различные качественные подходы реконструктивных манипуляций в стоматологической практике. Поиск первичных данных проводили с использованием поисковой системы Google Scholar по ключевым словам, с формулировкой поискового запроса в виде отдельных слов или словосочетаний. Выборка соответствующих публикаций осуществлялась с использованием метода контент-анализа, принципы использования которого позволили систематизировать результаты целевых научных исследований в программном обеспечении Microsoft Excel 2013 (Microsoft Office, 2013).

Результаты исследований и их обсуждение. Проведенный анализ применения принципов клеточной инженерии в стоматологической практике по данным клинических, лабораторных и экспериментальных исследований, позволяет сделать вывод о сложности систематизации полученных результатов, в связи с различным методологическим подходом к проведению исследований, использованием различных параметров оценки выходных и конечных результатов, и отличием целевого назначения того или иного метода регенераторной терапии - от фактического восстановления определенного объема костной ткани в подтверждении мысли о существующем регенераторном потенциале.

Выводы. Дальнейшая разработка и модисрикация существующих подходов регенеративной терапии материалами 3 поколения по Egusa (2012) обеспечивает повышение эффективности проведения различных типов реконструктивных вмешательств в челюстно-лицевой области, а отсутствие соответствующих алгоритмов управления стволовых клеток, их адекватного сбора и трансфера с последующей подсадкой остается актуальными вопросами регенераторной терапии в стоматологии.

Ключевые слова: клеточная инженерия; реконструктивные манипуляции; стоматологическая практика. 